Prezentarea terminologiei din domeniul fizicii

în manualele școlare

(clasele a VI-a - a IX-a)

\section{Presentation of the terminology from the area of Physics textbooks (VI-IX grades)}

Aliona Zgardan-Crudu, conferențiar univerențiar,

doctor în filologie,

\section{Catedra de Limbă și Literatură}

Română,

Facultatea de Filologie și Istorie, UPS ,Ion Creangă”, Chișinău

ORCID: 0000-0002-2969-4953

CZU: 811.135.1' 276.6:53(075)

\section{Rezumat}

În manualele de fizică pentru ciclul gimnazial, termenii sunt reluaţi de la o clasă la alta, prezentaţi, de obicei, în rubrici, în casete speciale.

Numărul termenilor studiaţi la fiecare temă nu este mare, astfel încât însuşirea lor să nu fie anevoioasă. În scopul relevării termenilor în text, ca aceştia să fie uşor de identificat şi memorat, s-a recurs la tehnoredactarea lor cu bold. În text, termenii sunt definiţi, explicaţi.

Profesorului îi revine o misiune foarte importantă la predarea termenilor, întrucât, cu ajutorul manualului şi al dicţionarului explicativ, ar putea contribui atât la instruirea elevilor în domeniul fizicii, cât şi la îmbogăţirea vocabularului acestora. Astfel, sar merge spre realizarea inter- şi transdisciplinarităţii, spre formarea elevului care conştientizează utilitatea, varietatea, importanţa cunoştinţelor achiziţionate în școlaritate.

Cuvinte-cheie: manual, cuvânt, termen, vocabular, terminologie, științe, inter-, transdisciplinaritate.

\section{Abstract}

In high school, in the Physics textbooks, the terms are repeated from one class to another, presented in sections, in special columns.

The number of terms studied in each topic is not large, so that their acquisition is not difficult. In order to reveal the terms in the text, so that to be easy to identify and memorize them, it's resorted to word's processing in bold. In the text, they are defined, explained. In this way, it would go towards achieving inter- and transdisciplinarity, towards emphasising the complex profile of the student, who is aware of the usefulness, variety, importance of the acquired knowledge.

The teacher has a very important mission of terms teaching, because, with the help of the textbook and the explanatory dictionary, he could contribute both to the training of students in the physics area and to the enrichment of their vocabulary.

Keywords: textbook, word, term, vocabulary, terminology, science, inter-, transdisciplinarity.

Termenii sunt cuvintele folosite pentru a desemna diferite noţiuni tehnice şi 
ştiinţifice. Ei formează aşa-numitul lexic special (terminologia), un microsistem căruia îi sunt proprii - ca şi întregului sistem lexical al limbii - antonimia, sinonimia şi chiar, în unele cazuri, polisemia.

Terminologia este ansamblul de termeni dintr-un anumit domeniu; deci aceștia formează terminologia domeniului respectiv: se vorbeşte, aşadar, despre terminologia medicală, agricolă, lingvistică, tehnică, militară etc.

Se poate face o paralelă între sistemul lexical (vocabularul) şi sistemul terminologic al limbii (terminologia): vocabularul este format din cuvinte, terminologia - din cuvinte-termeni. Totodată, terminologia, într-o limbă, constituie o parte din aceasta, din sistemul ei lexical, regăsindu-se în masa vocabularului.

În acest articol, mi-am propus să studiez prezentarea în manuale a termenilor pe care îi învață elevii la fizică în clasele gimnaziale, în legătură cu posibilitatea îmbogățirii vocabularului cu noi achiziții lexicale.

Studiind curricula, manualele şi ghidurile la fizică pentru ciclul gimnazial, am stabilit că termenii din domeniul fizicii se includ în varii categorii: termeni propriu-zişi, termeni monosemantici, termeni polisemantici, cuvinte care au sens terminologic. Numărul acestora este impunător, fiind reluaţi de la o clasă la alta, explicitaţi amănunţit.

În manualul de fizică pentru clasa a VI-a, la începutul fiecărei teme, termeniicheie ce urmează a fi studiaţi sunt dați întro casetă specială, cu genericul Termenicheie, iar la sfârşitul manualului este oferit şi un indice de termeni - Primul tău dicţionar de fizică -, în care aceştia sunt explicaţi cu ajutorul definiţiei. Pentru fiecare termen, este indicată pagina la care acesta este întâlnit, definit. Numărul termenilor studiaţi la fiecare temă nu este mare (doi-cinci), astfel încât însuşirea lor să nu fie anevoioasă. În scopul relevării termenilor în text, ca aceştia să fie uşor de identificat şi memorat, s-a recurs la tehnoredactarea lor cu bold. În text, ei sunt definiţi, explicaţi.

Termenii pe care îi studiază elevii în clasa a VI-a (din rubrica Termeni-cheie) sunt: fenomen fizic, fenomene (mecanice, termice, electromagnetice, optice); mărime fizică, valoarea mărimii fizice, valoarea unei diviziuni, eroarea absolută instrumentală, măsurare directă, inerție, densitatea substanței, densimetru; dilatare, contracție, echilibru termic, contact termic, reprezentare grafică, anomalie termică; corp neutru, corp electrizat, electrizare (prin frecare, contact, influență), conductoare electrice, izolatoare electrice, electroscop, sarcină electrică, coulomb, nucleu, electron, proton, neutron, sarcină electrică 
elementară, fulger, trăsnet, paratrăsnet, magnet, pol magnetic, regiune neutră; sursă de lumină, corp luminat, fascicul luminos, convergent, divergent, paralel, rază de lumină, corp (translucid, transparent, opac), mediu omogen, umbră, penumbră, eclipsă, elemente reflectorizante și fluorescente. Observăm că numărul lor nu este prea mare; în această listă întâlnim şi cuvinte pe care elevii este posibil să le fi auzit anterior, în diferite situaţii de comunicare. De exemplu, fulger, trăsnet, paratrăsnet, magnet, sursă de lumină, paralel, rază de lumină ş.a. Astfel, dintre aceşti termenicheie, sunt cunoscuţi de un număr mare de vorbitori şi se folosesc frecvent, nu doar în calitate de termen, următorii: inerție, reprezentare grafică, nucleu, fulger, trăsnet, magnet, convergent, divergent, paralel, rază de lumină, umbră, penumbră, eclipsă. Mai multe cuvinte dintre acestea pot servi în calitate de obiect de studiu pentru analiza semantică, în scopul stabilirii criteriilor care ar putea fi puse la baza delimitării termenului de cuvântul uzual, al înţelegerii faptului că există cuvinte monosemantice şi cuvinte polisemantice, care se utilizează cu diferite sensuri în diferite contexte. Este elocvent, în acest context, cuvântul polisemantic inerţie, care are sensurile: 1. (Fiz.) Proprietate a corpurilor de a-și păstra starea de repaus sau de mișcare în care se află atât timp cât nu sunt supuse acțiunii unei forțe exterioare. 2. Proprietate a unui sistem fizico-chimic sau tehnic de a reacționa slab sau cu întârziere la acțiunea factorilor externi. 3. Fig. Tendința unei persoane sau a unei colectivităţi de a rămâne în repaus, în inactivitate; lipsă de energie, indolență, apatie. 4. (Med.; în sintagma) Inerție uterină = lipsă de contracție și retractare a mușchiului uterin după naștere [4, s.v. inerție]. Asttfel, cuvântul inerție are trei sensuri terminologice (1, 2 şi 4), fiind cunoscut în domeniile fizicii, chimiei, medicinii şi tehnicii (pentru sensul 2, nu se indică domeniul în care cuvântul se utilizează cu acesta, dar, implicit, definiţia lexicografică sugerează că este vorba de fizică, chimie, tehnică), şi un sens conotativ, figurat (3). Observăm că acest cuvânt se utilizează atât în situaţii de comunicare legate de un anumit domeniu, cât şi cu scopul de a face comunicarea mai expresivă, cu sensul 3, figurat.

Termenul reprezentare grafică poate fi utilizat în orice ştiinţă, deoarece orice fenomen poate fi reprezentat grafic.

Pentru termenii fulger, trăsnet, magnet, convergent, dicţionarul explicativ nu indică domeniile în care se utilizează. Prezintă un interes deosebit cuvântul penumbră, care, conform dicţionarului explicativ, se utilizează ca termen în domeniul picturii, cu sensul terminologic 2: 1. Zonă incomplet luminată, cuprinsă între zona umbrită și cea luminoasă din 
spatele unui corp opac; zonă slab luminată; semiobscuritate. 2. (Pict.) Suprafață slab luminată aflată la confluența luminii cu umbra [4, s.v. penumbră].

În afară de aceştia, în manual, la fiecare temă, sunt explicaţi, definiţ̧i, exemplificaţi şi alţi termeni, la fel de importanţi ca şi cei din rubrica Termenicheie. Numărul lor este mai mare decât al celor consideraţi termeni-cheie, incluzând şi cuvinte care sunt termeni cunoscuţi şi utilizaţi şi în alte domenii, ştiinţe: observare, experiment, raţionament, substanţe, măsurare, etalon, etalonul metrului, forță, direcţie, sens, mărimi vectoriale, inerţie, masă, kilogram, etalon; dar şi cuvinte care şi-au pierdut parţial caracteristica de termen, supunându-se fenomenului determinologizării, fiind întâlnite în vorbirea mai multor persoane și în contexte care nu au nimic în comun cu fizica: substanţă, cântărire, lichide, gaze, temperatură, termometru, izolator, neutralizare, fulger, tunet, trăsnet, paralel, convergent, rază de lumină, con de umbră, penumbra, eclipsa de Soare, eclipsă ş.a., de multe ori cu sens figurat, ocazional (de exemplu: fulger, trăsnet, eclipsă, con de umbră). Pentru celelalte cuvinte, dicţionarul indică sau sugerează că sunt termeni ori au un sens terminologic.

$\mathrm{Cu}$ referire la termenii care nu sunt prezentaţi în rubrica Termeni-cheie, menționăm că aceştia se pretează la o interpretare şi la o analiză mai largă, în virtutea faptului că pot fi sistematizaţi, grupaţi în mai multe categorii, chiar în câmpuri lingvistice. De exemplu, termenii observare, experiment, raţionament desemnează metode care se aplică în toate ştiinţele; măsurare, etalon, forţă, direcţie, cristale, temperatură, termometru, izolator, fulger, tunet, busolă, trăsnet, fascicul de lumină, divergent, paralel, convergent, rază de lumină, mediu omogen, umbră, con de umbră, penumbra, eclipsă se folosesc şi în calitate de cuvinte uzuale, în comunicarea cotidiană; sens se utilizează în primul rând în lingvistică, masă, kilogram, cântărire în matematică etc.

Consider că profesorului îi revine o misiune foarte importantă, la predarea termenilor din domeniul fizicii, întrucât, cu ajutorul manualului şi al dicţionarului explicativ, acesta poate contribui atât la instruirea elevilor în domeniul fizicii, cât şi la îmbogăţirea vocabularului lor, la înţelegerea de către ei a complexităţii, frumuseţii şi bogăţiei limbii române. În felul acesta, se ajunge la realizarea inter- şi transdisciplinarităţii, la formarea unui elev care conştientizează utilitatea, varietatea, importanţa cunoştinţelor achiziţionate în școlaritate.

În manualul pentru clasa a VII-a, termenii nu sunt prezentaţi, ca în manualul pentru clasa a VI-a, într-o rubrică specială. Aceştia sunt definiţi şi explicaţi în text. La sfârşitul manualului, este dată o listă de 
termeni - Conceptele de bază studiate în clasa a VII-a la fizică -, în care sunt prezentaţi în ordine alfabetică şi definiţi, ca în Primul tău dicţionar de fizică din manualul pentru clasa a VI-a.

Dintre termenii din Conceptele de bază studiate în clasa a VII-a la fizică, deplasare, drum parcurs (sau distanță parcursă), inerție, repaus, interacţiune, lucru util, mecanisme, pârghie, plan inclinat, poziția corpului, presiune, echilibru, presiune atmosferică, scripete, sistem de referință, traiectorie, vase comunicante sunt utilizaţi şi în afara fizicii, în vorbirea cotidiană, dar şi în biologie, geometrie, algebră (traiectorie, vase comunicante, viteza corpului), unii făcând parte chiar din lexicul activ al unor persoane, întrucât, polisemantici fiind, majoritatea dintre ei cunosc o utilizare largă, graţie faptului că denumesc şi obiecte de uz general, necesare frecvent în varii activităţi pe care le realizăm. De exemplu, se utilizează frecvent, în contexte diferite, deplasare, presiune, drum parcurs ş.a. Remarcăm că majoritatea acestor termeni sunt noi pentru elevi, întrucât nu au fost studiaţi în clasa a VI-a, cu excepţia lui inerţie.

În afară de termenii din Conceptele de bază studiate în clasa a VII-a la fizică, în manual sunt prezentate, definite, explicate și alte cuvinte, numeroase, tehnoredactate cu bold, dintre care unele sunt termeni utilizaţi doar în domeniul fizicii, iar altele se întâlnesc şi în comunicarea cotidiană, nefiind termeni propriu-zişi. O parte din aceşti termeni (nu prea mulţi) sunt explicaţi în indicele de la sfârşitul manualului, majoritatea însă fiind noi, nemaiîntâlniţi anterior, în clasa a VI-a. Alţi termeni le sunt cunoscuţi elevilor din clasa a VI-a: corp, joule, masă, inerţie ş.a. Unii termeni de aici se utilizează, de asemenea, în matematică, lingvistică (distanţă, poziţie, punct, timp etc.).

În clasa a VIII-a, la fiecare temă sunt prezentaţi, în rubrica Conceptele studiate recent, de la trei până la 13 termeni, fără definiţie, ca în rubrica Termeni-cheie din manualul pentru clasa a VI-a. La sfârşitul manualului, este dat un indice de termeni Conceptele de bază studiate în clasa a VIII-a la fizică -, în care aceştia sunt sistematizaţi după capitole, în ordine alfabetică.

Mai mulţi termeni din lista Conceptele de bază studiate în clasa a VIII-a la fizică sunt predaţi şi în clasele a VI-a şi a VII-a, majoritatea însă fiind noi pentru elevi. Tot aşa, putem identifica, în această listă, termeni din domeniul fizicii, termeni care se utilizează şi în alte ştiinţe, cuvinte care, polisemantice fiind, în anumite contexte, se detaşează de statutul de termen şi sunt utilizate pe larg în comunicarea oamenilor care nu activează în domeniul fizicii. De exemplu: frecvenţă, perioadă, vaporizare, condensare, fierbere, topire, solidificare, combustibili, putere, bobină ş.a. Unii 
termeni (cuvinte, sintagme) căpătă conotaţie. Se atestă, în felul acesta, o omonimie, ce-i drept, la nivelul vorbirii, ocazională, a termenului cu un cuvânt sau cu o expresie care are conotaţie. De exemplu, solenoid este utilizat în calitate de titlu al cunoscutei opere a lui Mircea Cărtărescu, lungime de undă este prezent în structura expresiei frazeologice a fi pe aceeaşi lungime de undă.

În clasa a IX-a, termenii sunt definiţi în cadrul temelor; nu există în manual vreo rubrică sau vreun indice de termeni (la sfârşitul manualului), ca la celelalte clase. $\quad \hat{n}$ mare parte, termenii sunt noi, nemaiîntâlniţi anterior. Mai mulţi termeni de aici sunt studiaţi şi la biologie (membrană sclerotică a ochiului, cornee, irisul colorat, pupilă, umoare apoasă, cristalin, umoare sticloasă, retină, nerv vizual, cornee, cristalin, sistemul optic al ochiului, ochi normal).

Pornind de la aceşti termeni, dar şi de la alţii, selectaţi cu minuţie şi acribie, profesorul poate face legături interdisciplinare, poate trezi interesul elevilor pentru fizică şi legile ei, care sunt vii, prezente în viaţa de toate zilele şi de aceea importante pentru cunoaşterea umană; totodată, dacă profesorul de fizică este solidar cu profesorul de limbă și literatura română, în intenția de a forma nu doar un cunoscător al fizicii și al legilor ei, ci și al frumuseții limbii române, al normelor ei, se realizează un lucru minunat: formarea, la lecțiile de fizică, a competenței de comunicare.

În concluzie, menționez că prezentarea termenilor în manualele de fizică pentru ciclul gimnazial proiectează buna asimilare de către elevi a materiei, fiind bine selectați, sistematizați, explicaţi, exemplificați. Profesorului de fizică i se oferă un teren fertil pentru realizarea la lecție a inter- și transdisciplinarității, a legăturii dintre disciplinele fizica și limba şi literatura română, în scopul formării unui elev care va proba, în viitor, în varii situații de viaţă, că este un vorbitor cult, inteligent, prin cunoaşterea terminologiei fizice, însuşite în școlaritate.

\section{Bibliografie}

1. BOTGROS, Ion et al. Fizică. Manual pentru clasa a VII-a. Ediția a IV-a, actualizată. Chişinău: Cartier Educaţional, 2018.

2. BOTGROS, Ion et al. Fizică. Manual pentru clasa a VIII-a. Ediția a IV-a, actualizată. Chişinău: Cartier Educaţional, 2019.

3. BOTGROS, Ion et al. Fizică. Manual pentru clasa a IX-a. Ediţia a III-a, revăzută şi adăugită. Chişinău: Cartier Educaţional, 2016.

\section{Webografie}

4. https://dexonline.ro/definitie/penu mbr\%C4\%83 (vizitat la 23.02.2021). 